\title{
Key Influences on the Initiation and Implementation of Inclusive Preschool Programs
}

\section{JOAN LIEBER \\ University of Maryland \\ MARCI J. HANSON \\ San Francisco State University \\ PAULA J. BECKMAN \\ University of Maryland \\ SAMUEL L. ODOM \\ Indiana University \\ SUSANDR. SANDALL \\ ILENE S. SCHWARTZ \\ University of Washington}

EVA HORN

University of Kansas

RUTH WOLERY

Vanderbilt University

ABSTRACT: Inclusion is a challenging educational practice to implement at the preschool level. We interviewed early childhood teachers, related services providers, program directors, and state-level administrators in 18 public schools, Head Start, and community-based programs in four geographical regions across the United States. Interviews were analyzed to determine factors that were facilitators of or barriers to the development of inclusive preschool programs and to describe where inclusion began for each of the programs. Key personnel was the strongest facilitator of inclusion across all programs. Other important influences were the provision of training and external support, holding a shared vision, and the impact of national and state policies.

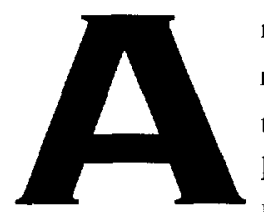

n extensive literature documents the efforts of schools to adopt innovations that lead to systemic change (see Fullan, 1991; Hargreaves, 1997; Huberman \& Miles, 1984). McLaughlin (1990) reviewed findings of the Rand Corpora- tion study of four federally funded programs that promoted school district change. Although federal policies were important to "prompt" school districts to undertake change, those efforts were not uniformly successful. Successful change occurred in districts that had active commitment of their leadership from the beginning 
and who implemented change incrementally rather than across the whole system at once. McLaughlin also listed strategies that benefited teachers who were attempting change in their classrooms. These included teacher participation in project decisions, opportunity to observe other teachers implementing similar projects, classroom assistance, and individualized, ex tended training.

Fullan (1991) identified similar factors fa cilitating the initiation and implementation of educational change, specifically the impetus for change emanating from a new policy, and the importance of advocacy from the district admin istration. Fullan identified other facilitative fac tors during the initial stages of innovation. One factor was external change agents who were valuable in helping districts to develop initial plans, conduct initial training, and provide on going support and evaluation Community sup port was also important, as was access to information. In districts where central office personnel had personal contacts and the oppor tunity to attend conferences or workshops, they learned about the latest innovations and brought that information back to their district.

One of the more recent educational inno vations that have been inspired by changes in public policy is inclusion, leading to increased access of children with disabilities to public school classrooms (Cuban, 1996). Inclusion as a systemic change had its roots in the passage of the Education for All Handicapped Children Act in 1975, and was reaffirmed in 1997 with the reauthorization of the Individuals with Dis abilities Education Act (IDEA). For preschoolers with disabilities, the principle that their education should take place with their typically developing peers is particularly difficult to implement. Although service for preschool children with disabilities is required by public law, many public school systems do not have classes of 3- to 5-year-old typically developing children into which children with disabilities may be included.

Programs have met this challenge by serv ing young children with disabilities in a variety of settings (Odom et al., 1999). In a study of 16 programs in four regions of the country, Odom et al. found that preschoolers attended inclusive programs in a variety of organizational contexts. Some attended state funded prekindergarten programs, or public school programs that were combined with Head Start or with child care. Still others attended community based child care programs or Head Statt, unaffiliated with public schools.

Systems' efforts to provide inclusive pro grams for preschoolers are reflected in the in crease in numbers of children with disabilities served in these programs in the past 10 years. For example, Wolery et al. (1993) reported that from 1985 to 1990 the numbers of programs that enrolled at least one child with a disability almost doubled (from $38 \%$ of the 483 programs surveyed to $74 \%$ ). Like Odom et al. (1999), Wolery et al. found that preschoolers were served in Head Start, prekindergarten, and com munity programs. Although numbers of chil dren served in inclusive programs are increasing, inclusion is an educational innovation that is not universal at the preschool level (McDonnell, Brownell, \& Wolery, 1997)

Peck and his colleagues conducted a series of studies to identify factors that led some sys tems to adopt inclusion for preschoolers (Peck. Furman, \& Helmstetter, 1993; Peck, Hayden, Wandschneider, Peterson, \& Richarz, 1989; Peck, Richarz et al., 1989). Using a case study description of one school district, Peck, Richarz et al., found that factors that facilitate change in programs for school aged children operate at the preschool level as well. In a small school district, the move to inclusive services began when a legislative mandate to provide services to preschoolers with disabilities co occurred with leadership support from central office adminis trators (superintendent, director of special edu cation) and with external support (university faculty and a regional consultant). Peck, Richarz et al., documented the district's planning process that incorporated many of the successful strate gies described by Fullan (1991) and McLaughlin (1990). For example, the change proceeded in crementally with partial inclusion of some stu dents, and classroom staff partucipated in program design. Peck, Richarz et al., identified other factors that facilitated adoption of the in novation. These factors included development 
of a joint philosophy that captured the views of all participants, and provision of joint training.

Not all attempts to adopt an educational innovation are successful, however. Factors that facilitate change under some circumstances, are barriers on other occasions. For example, Hargreaves (1997) identified conditions under which leaders, key staff, community advocates, and the nature of the change itself can impede adoption of the innovation. In a specific example, Peck, Hayden et al. (1989) interviewed administrators, teachers, and parents involved in the development of an inclusive program in Washington and identified barriers to its adoption. Among their concerns were adequate provision for training and willingness of key staff members and community advocates (especially parents) to adopt the innovation and integration of program philosophies from the early childhood and special education programs.

Harvey, Voorhees, and Landon (1997) also studied factors that contributed to the development of inclusive preschool programs in Virginia. Using focus groups of key stakeholders-early childhood education administrators and teachers, early childhood special education administrators and teachers, parents of preschoolers with disabilities, and university faculty members who were collaborating with these programs, they asked the groups to identify concerns and issues surrounding the creation of inclusive programs. Although this study differs from those of Peck and his colleagues because recommendations were directed at the state-level policymakers, concerns identified in the focus groups share similarities with the findings of Peck, Hayden et al. (1989). Specifically, the focus groups pointed to staff development needs as critical at the program level, including joint training, and opportunities to observe quality programs.

Although Peck and his colleagues and Harvey et al. (1997) have provided an impressive beginning to identifying local factors that facilitate or impede the adoption of inclusive programs for preschoolers, information about this topic is limited. Previous studies focused on one state or on one organizational context. This article adds to the existing research by (a) describing factors that were facilitators of or barri- ers to the development of inclusive preschool programs; (b) contrasting those factors across programs that represented a variety of organizational contexts in which inclusive services for preschoolers are provided in four geographic regions of the United States; and (c) describing the range of system levels where an innovation can begin for individual preschool programs.

\section{METHOD}

This study was part of a larger multisite investigation of inclusion in early childhood settings conducted by the Early Childhood Research Institute on Inclusion (ECRII). The primary purpose of the ecological systems study was to identify the facilitators of and barriers to inclusion for preschool children and their families. In the current study, we identified barriers and facilitators as they applied to the initiation and implementation of the programs themselves.

\section{Settings and Participants}

This study was conducted at four regional locations in the West, East, Southeast, and Northwest. Investigators at each regional site invited participation from four programs that identified themselves as inclusive. All 16 programs agreed to participate. The programs varied considerably in their approach to including young children with disabilities. One constant across programs was the participation of children with and without disabilities in joint activities.

We used a purposive sampling procedure to maximize variation among the programs (Lincoln \& Guba, 1985), selecting public school, community-based, and Head Start programs from rural, suburban, and urban settings in the four geographic regions. In Table 1, we describe each program, its organizational context, and where inclusion began for that program. Additionally, we characterize each program as "early" or "late." Early programs are those that became inclusive prior to 1991 , when services for preschoolers with disabilities became mandatory. Late programs implemented inclusion after that date. Finally, we provide demographic information about the program including socioeconomic status (SES) of families 
TABLE 1

Programs and Characteristics

\begin{tabular}{|c|c|c|c|c|c|}
\hline Name and Location & $\begin{array}{c}\text { Organizational } \\
\text { Context }\end{array}$ & $\begin{array}{c}\text { Where Inclusion } \\
\text { Started }\end{array}$ & $\begin{array}{l}\text { Early or Late } \\
\text { Adoption of } \\
\text { Inclusion }\end{array}$ & Location & Family SES \\
\hline $\begin{array}{l}\text { Valley View, } \\
\text { WA }\end{array}$ & Public School & $\begin{array}{l}\text { Classroom-through } \\
\text { a teacher }\end{array}$ & Early & Rural & Middle \\
\hline $\begin{array}{l}\text { Rolling Hills- } \\
\text { Hubert Co., TN }\end{array}$ & Head Start & Classroom & Late & Rural & Low \\
\hline $\begin{array}{l}\text { Costa Mesa, } \\
\text { CA }\end{array}$ & Public School & Classroom & Early & Urban & Low-Middle \\
\hline $\begin{array}{l}\text { Winwood, } \\
\text { MD }\end{array}$ & Public School & $\begin{array}{l}\text { Classroom-through } \\
\text { building principal }\end{array}$ & Late & $\begin{array}{l}\text { Urban/ } \\
\text { Suburban }\end{array}$ & Low \\
\hline $\begin{array}{l}\text { Beacon Street, } \\
\text { MD }\end{array}$ & Public School & $\begin{array}{l}\text { Classroom-through } \\
\text { building principal }\end{array}$ & Late & Urban & Low-Middle \\
\hline $\begin{array}{l}\text { Briar Brook, } \\
\text { MD }\end{array}$ & Public School & System-level & Late & Suburban & Middle \\
\hline $\begin{array}{l}\text { Hidden Trails, } \\
\text { WA }\end{array}$ & $\begin{array}{l}\text { Public School } \\
\text { Head Start }\end{array}$ & System-level & Early & Suburban & Low-Middle \\
\hline $\begin{array}{l}\text { Hathaway, } \\
\text { CA }\end{array}$ & Public School & System-level & Early & Urban & Low-Middle \\
\hline $\begin{array}{l}\text { Cornwallis, } \\
\text { MD }\end{array}$ & Public School & System-level & Late & Urban & Low \\
\hline VIP, TN & $\begin{array}{l}\text { Public School } \\
\text { Community- } \\
\text { Based Child care }\end{array}$ & System-level & Late & $\begin{array}{l}\text { Urban/ } \\
\text { Suburban }\end{array}$ & Low-Middle \\
\hline $\begin{array}{l}\text { Lincoln County, } \\
\mathrm{KY}\end{array}$ & Public School & System-level & Late & $\begin{array}{l}\text { Urban/ } \\
\text { Suburban }\end{array}$ & Low-Middle \\
\hline $\begin{array}{l}\text { Northumberland- } \\
\text { Mayberry, TN }\end{array}$ & $\begin{array}{l}\text { Head Start } \\
\text { Public School }\end{array}$ & System-level & Late & $\begin{array}{l}\text { Rural/ } \\
\text { Suburban }\end{array}$ & Low-Middle \\
\hline $\begin{array}{l}\text { Northumberland- } \\
\text { Winter Co., TN }\end{array}$ & $\begin{array}{l}\text { Head Start } \\
\text { Public School }\end{array}$ & System-level & Late & $\begin{array}{l}\text { Rural/ } \\
\text { Suburban }\end{array}$ & Low-Middle \\
\hline $\begin{array}{l}\text { Rolling Hills- } \\
\text { Samson Co. TN }\end{array}$ & Head Start & System-level & Late & Rural & Low \\
\hline $\begin{array}{l}\text { Vista Valley, } \\
\text { CA }\end{array}$ & Head Start & System-level & Late & Rural & Low-Middle \\
\hline $\begin{array}{l}\text { Building Blocks, } \\
\text { WA }\end{array}$ & Head Start & System-level & Late & Urban & Low \\
\hline $\begin{array}{l}\text { Santa Luna, } \\
\text { CA }\end{array}$ & Head Start & System-level & Early & $\begin{array}{l}\text { Urban/ } \\
\text { Suburban }\end{array}$ & Low \\
\hline $\begin{array}{l}\text { City Center, } \\
\text { WA }\end{array}$ & $\begin{array}{l}\text { Community- } \\
\text { Based Child care }\end{array}$ & System-level & Early & Urban & Low-Middle \\
\hline
\end{tabular}

Note: $\mathrm{SES}$ = socioeconomic status of families. 
whose children attended the program. The SES for the programs was characterized in terms of the predominant income levels of participating families. More detail about these programs may be found in Odom et al., 1999.

Although the focus for the ecological systems study was on 16 programs, 2 of the programs in one region (Northumberland and Rolling Hills) were Head Start programs served by different school districts. Since the impetus for inclusion played out differently in these school districts, we represented that difference by listing each of the programs separately.

\section{DATA COLLECTION}

An ecological systems approach (Bronfenbrenner, 1979) provided the conceptual framework for our data collection. In our data collection we explored participants' perspectives across multiple levels of the system. Although the larger study explored the perspectives of constituents across school, home, and community contexts; the data presented here are the perspective of teachers and administrators at the program, district, and state levels in the school context. To capture this perspective, we held open-ended interviews, using a standard protocol. In all settings (public school, Head Start, and community-based child care) we interviewed classroom teachers-both early childhood educators and early childhood special educatorsand related services providers. Also in each setting, we interviewed school principals, Head Start directors, program administrators, school district administrators for early childhood special education, or district directors of special education. Table 2 shows the number of interviews with each of these professionals. Last, in each region, we interviewed the 619 coordinators (i.e., state-level administrators responsible for services for preschool children with disabilities) for that state.

Although the interviews covered a variety of topics, for the purpose of this article, the relevant questions pertained to the history of inclusion for the program, district, or state; perceptions about the barriers and facilitators of inclusion; and definitions of inclusion. We were interested in how inclusion began at a particular site. For eight of our programs this information was about recent events because inclusion began as an innovation within 1 year of initial data collection at those sites. For 10 programs the interviews were retrospective because inclusion began at least 2 years before our initial interviews. Interviews lasted between 30 and $90 \mathrm{~min}$, and they were audiotaped and transcribed. In many cases, staff members also provided written materials relevant to the program.

\section{DATA ANALYSIS}

Interviews were coded using the constant comparative method advocated by Glaser and Strauss (1967) as a means to yield concepts grounded in data. Coding, a sorting and categorizing process that assigns labels to meaningful regularities in the data, is an inductive, recursive process. It began early in data collection in order to flesh out, extend, and test emerging categories (Lincoln \& Guba, 1985).

Initially, researchers identified units of meaning within the interviews, labeling them to reflect individual understandings of the data. Next, to ensure reliability in coding, researchers at each site met weekly to review initial codes, generate hierarchies of categories that represented the data, and develop interpretations of emerging categories.

Cross-Site Analysis. Six months into data collection, a process of cross-site analysis began. Researchers from the four university sites met with an experienced ethnographer to synthesize and define the major conceptual categories emerging from data collected across sites. Out of this process, researchers developed questions and planned additional data collection to explore and develop these categories. One of the major conceptual categories identified during this stage of cross-site analysis was key influences to the initiation and maintenance of inclusive programs. In this article our focus is on factors associated with program initiation and implementation that served as either facilitators or barriers to this process.

The first step in the next level of analysis was to determine where inclusion began at each site (i.e., in an individual classroom, through the efforts of building principal or program administrator, or at a system level). Subsequently, researchers examined the transcripts to identify 


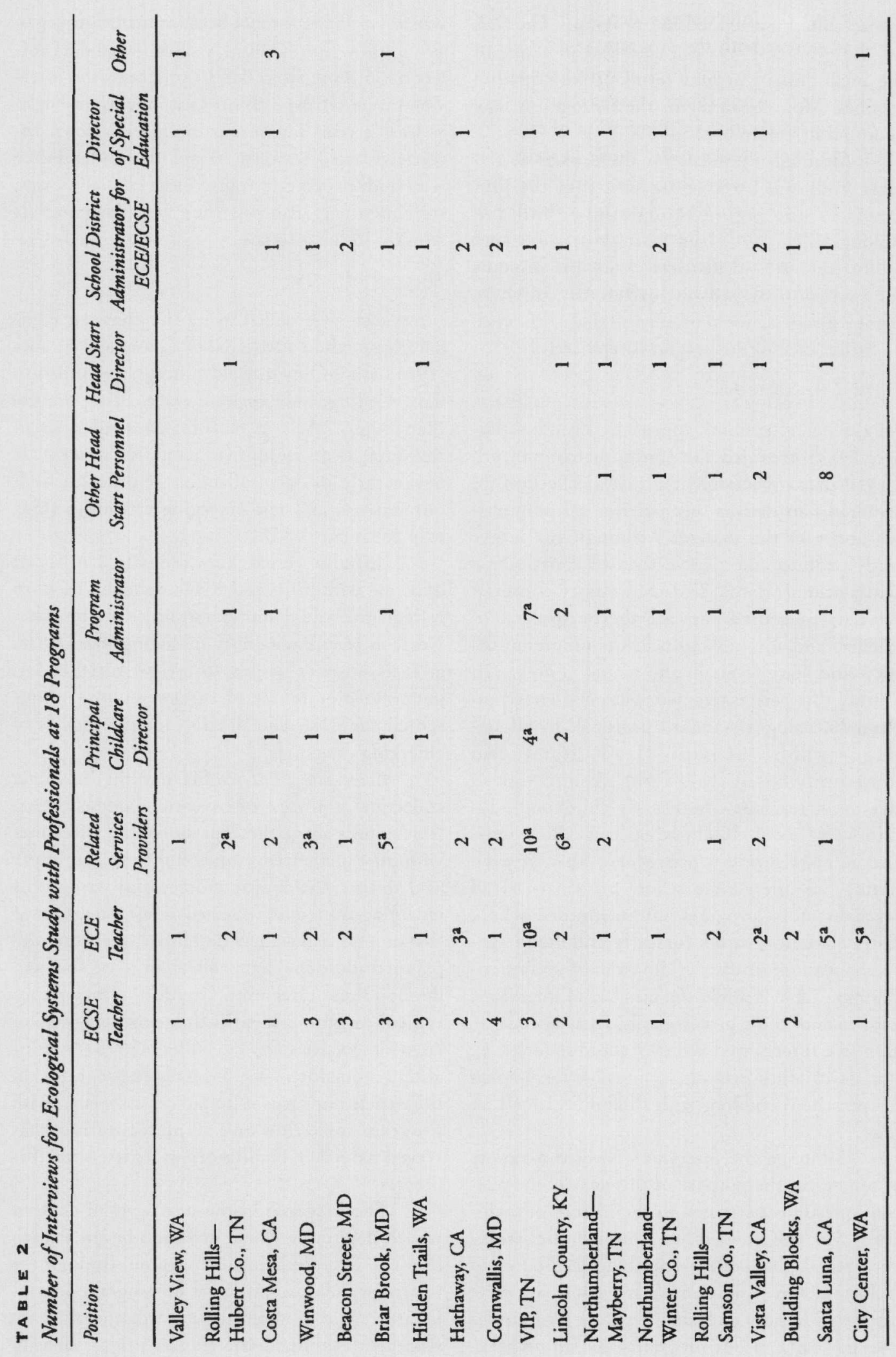

88 
factors that the interviewees identified as critical for inclusion at both the program or district levels, regardless of which level provided the impetus for the innovation. Researchers then developed a definition or description of each factor. Using conference calls, those descriptions were shared with researchers cross-site, who then reviewed their own site's data for evidence of those factors. We further determined, for each site, if each factor had a positive, negative, or no influence on the implementation of inclusion at that program.

Member Check. To determine the accuracy of our interpretation of the data, researchers did member checking at each site. At some sites, research staff gave key informants (e.g., early childhood school district administrator) a completed matrix that summarized the data analysis and asked for their reaction. At other sites, a verbal summary was provided. In all cases, changes were made to our interpretations based on the information provided by the key informant.

\section{RESULTS}

\section{PoInt of Initiation fOR INCLUSION}

As we noted previously, inclusive programs for preschool children differ from those for schoolaged children because many public school systems do not have classes of 3-to 5-year-old typically developing children into which children with disabilities may be included. As a result, at the preschool level children are served in a variety of settings including community-based child care or Head Start programs as well as in public school classrooms. This diversity is reflected in the different organizational contexts for our programs, and differences in where inclusion began as an innovation for each particular setting in our sample.

We found that programs developed differently depending on where the impetus for inclusion came. For some programs the impetus came from a teacher in a single classroom and remained at that level. For other programs, a single principal provided the impetus for several teachers in a school. In other cases, the director of special education in a school district spear- headed a movement to implement inclusion on districtwide basis and included preschool programs. As shown in Table 1 , in 13 of 18 programs, the decision to initiate inclusion came at a system level. In 5 of the 18 programs, inclusion began through a teacher's efforts, or with the vision of a principal at a single school.

Initiation at the Classroom or School Level. In two of the organizational contexts, public school and Head Start, the impetus for inclusion began with a single classroom or school. At Valley View the lead teacher started the program over 10 years ago and has been its primary champion. She and her colleagues created a program housed in a high school that serves preschoolers with and without disabilities. High school students who attend a vocational program participate as assistants in the preschool classroom.

In two other public school programs, principals initiated the inclusive programs. At Beacon Street, the principal envisioned inclusive classes throughout her elementary school, starting at the preschool level. According to the prekindergarten teacher, "The principal approached us [her and a special education teacher] about co-teaching and doing an inclusion program. She gave us the opportunity to design it and do it any way we wanted to."

Another public school program was housed in an early childhood center that served children from birth through age 8 . For preschoolers, there were special education, Head Start, and state-funded prekindergarten programs. This program's principal initiated inclusion using a "buddy class" model for the preschool children, putting special education and early childhood education classes near each other to facilitate joint activities.

In still another program, families provided the impetus for inclusion in one Head Start program. For example, when Benny was identified as having a disability, his family insisted on Head Start instead of the public school's selfcontained multiage special education program.

Initiation at the System Level. In our sample, the impetus for inclusion came more often at a system level. In some cases the school district alone provided the impetus for the innovation; in other cases, multiple agencies (e.g., 
Head Start and the public schools) collaborated to develop the program.

In four of the public school programs, inclusion was a district-level innovation. For example, in one program, the director of special education for the school district wrote a strategic plan in which she described her vision for inclusion. During the next year, inclusion began in many elementary schools throughout the district with resources provided to the schools that implemented it. At the same time, children without disabilities were included in four of the district's early childhood special education programs.

In three public school programs, inclusion was initiated at the system level; however, the focus was on the early childhood level, rather than across the system. In the VIP program, for example, the school district formed a Preschool Task Force to focus on the provision of inclusive services. Simultaneously, a new superintendent and a special education coordinator were hired. These factors led the school district to implement a model of full inclusion in which special education services were provided on an itinerant basis to preschoolers placed in community-based child care programs.

For three programs the innovation began as a collaborative effort between two agencies: public school and Head Start. In Vista Valley, the relationship between the public school and Head Start program had a long history, and available space at a county site provided an impetus for the programs to work together. The space provided an ideal opportunity for Vista Valley Head Start and the county early childhood special education program to forge a partnership. This partnership emerged from the vision and leadership of two pivotal players, the Head Start director and the infant/preschool administrator for the County Office of Education. By establishing an interagency agreement, they located two Head Start preschool classes on the county site and carefully fashioned a model for full inclusion.

Two programs were Head Start programs with minimal or poor relationships with the public schools. Because Head Start regulations require that at least $10 \%$ of the children they serve have disabilities, these programs were in- clusive. In the case of both Building Blocks and Santa Luna, the public schools offered primarily segregated programs for other preschoolers with disabilities who did not attend Head Start.

City Center offered an inclusive program that was unique in our sample. The system responsible for the preschool program was an agency that provided services for people with mental retardation (MR). It began by serving people of all ages, and in 1978 its childcare program began including children without disabilities.

We provide these examples to show that when preschool inclusion begins as an innovation in a particular locality, it does so in ways that are both similar to and different from innovation in K-12 programs. Innovations at the preschool level are unique when they begin as a result of joint agency agreements and when preschool innovations are used as a low-risk model for the rest of the school district.

\section{KEY INFLUENCES IN THE INITIATION AND IMPLEMENTATION OF INCLUSIVE PRESCHOOL PROGRAMS}

Programs in our sample took a variety of paths to become inclusive. However, across these diverse programs, six common factors influenced initiation and implementation of the inclusive preschool programs. The key influences and their descriptions are provided in Table 3 . These influences operated differently in different programs. In some cases they facilitated the development of inclusion; in other cases they were barriers. The direction of their influence on individual programs is shown in Table 4.

Key Personnel. The strongest facilitator of inclusion across all programs in our sample was key personnel. The people who were instrumental varied ranging from teachers to the superintendent of a district's schools. For example, the teachers at Beacon Street facilitated inclusion in their program. As one teacher said,

We [she and her co-teacher] were recruited to do this and we both bought into it. I had not been in a classroom for some time when I came back to Beacon Street school. Gwen had been teaching prekindergarten for 10 years. We spent our summer preparing for this. We talked and we found we were of like mind when it 
TABLE 3

Descriptions of Key Influences on Initiation and Implementation of Inclusive Programs

Key Influence

Description

Personnel

The influence of a specific person or people employed by the program on inclusive practices in the program. Influence may be ongoing, may be sparked by an event (hearing a presentation), may be sparked by previous experience, or may wane (e.g., a charismatic leader whose interests turn to a new innovation).

Shared Vision

National, State, Local Policies and How They're Enacted

Training and External Support

Organizational Structure

Community Influence
The transformation of the concept of inclusion that occurs over time among those who design, deliver, or use inclusive education so that it includes the views of all participants.

Policies established by national (Head Start or OSEP) or state agencies that influence practices that occur in local programs. Examples of these influences are the LRE provisions from P.L. 94-142, the Head Start " $10 \%$ " mandate for children with disabilities, and state or regional level administrators' enactment or enforcement of policies at the classroom level.

Any money, training, other type of support, or special recognition beyond regular program money or support that is associated with the startup of a program.

Structures that exist within a district and between different agencies so that people can communicate, collaborate, and share resources. This includes formal interagency agreements.

Influence exerted by community members (e.g., families) who are not employees of the school district or other agencies such as Head Start. came to where we wanted to take children and what our philosophy was .... We like to think of ourselves as an instructional team and we really do co-teach. We're almost like one person. It's gotten so bad that, at times, we even finish each other's sentences.

In Lincoln County, the school superintendent facilitated inclusion's development at the district level. The superintendent, who arrived in 1992, was a strong proponent of early childhood education (ECE) programs. He was described as having a "vision that a preschool experience should be available to every child or family that wishes it; that children shouldn't be transported beyond programs for which they don't qualify to others that they do; and that they should be attending their neighborhood schools." He appointed a deputy superintendent for Community Development who had a reputation as a "can-doer" to carry out his vision re- garding ECE. Because of the superintendent's vision, all early childhood programs--including Head Start, state prekindergarten, and the early childhood special education (ECSE) programswere coordinated in one division; and, therefore, all public preschool programs served as placements for preschool children with disabilities.

In some programs key personnel were barriers to inclusion. For example, in the team teaching program in Winter County, the teachers were not prepared for inclusion. Children with disabilities began the school year earlier than the typically developing children. When the children with disabilities began their program, they moved into a classroom that had been occupied by the Head Start teacher for the previous 4 years. The Head Start teacher came back to school to find her room completely rearranged. As she said, "You know, it's like if you leave home on vacation and you come back and all of 


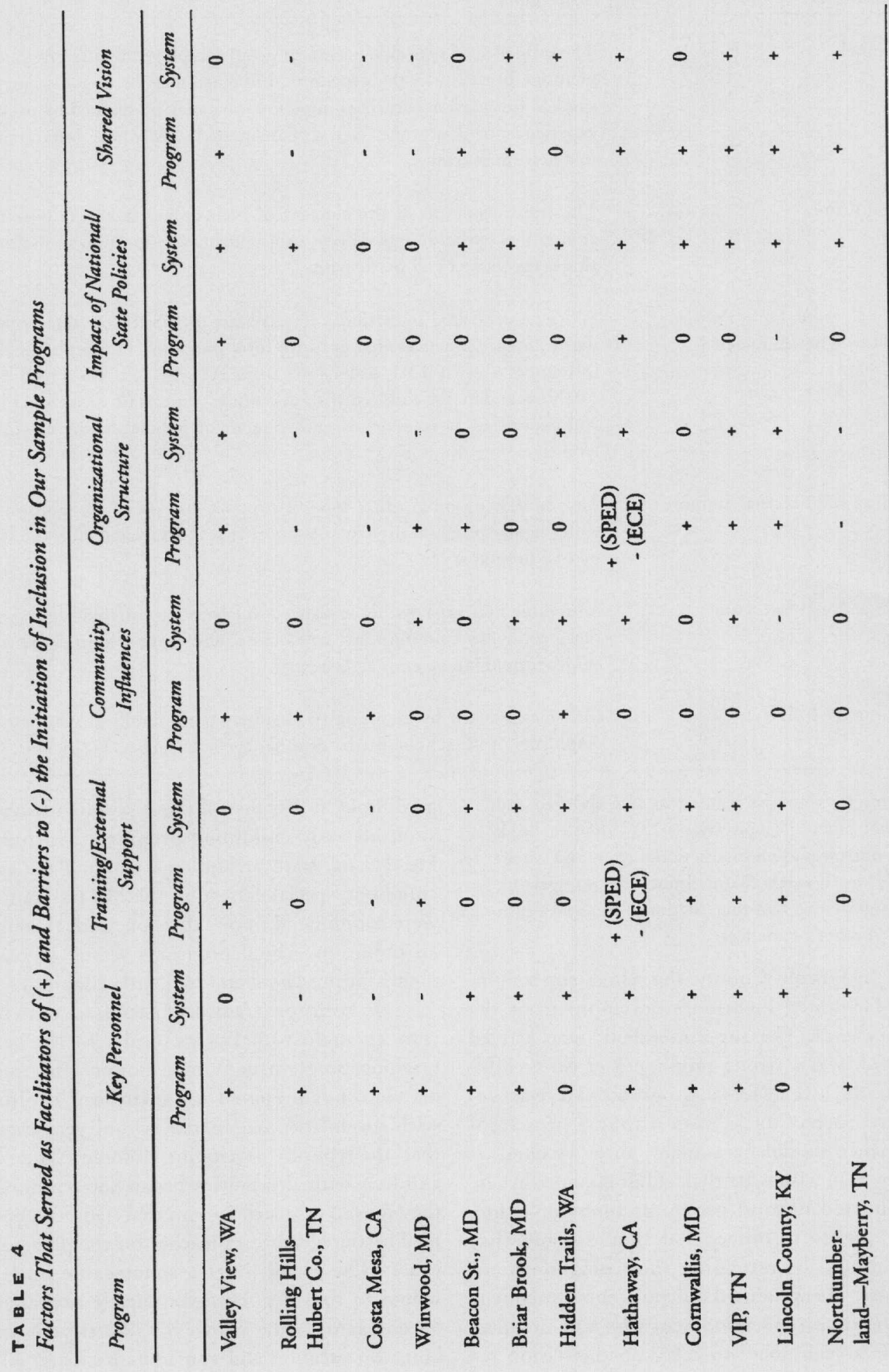




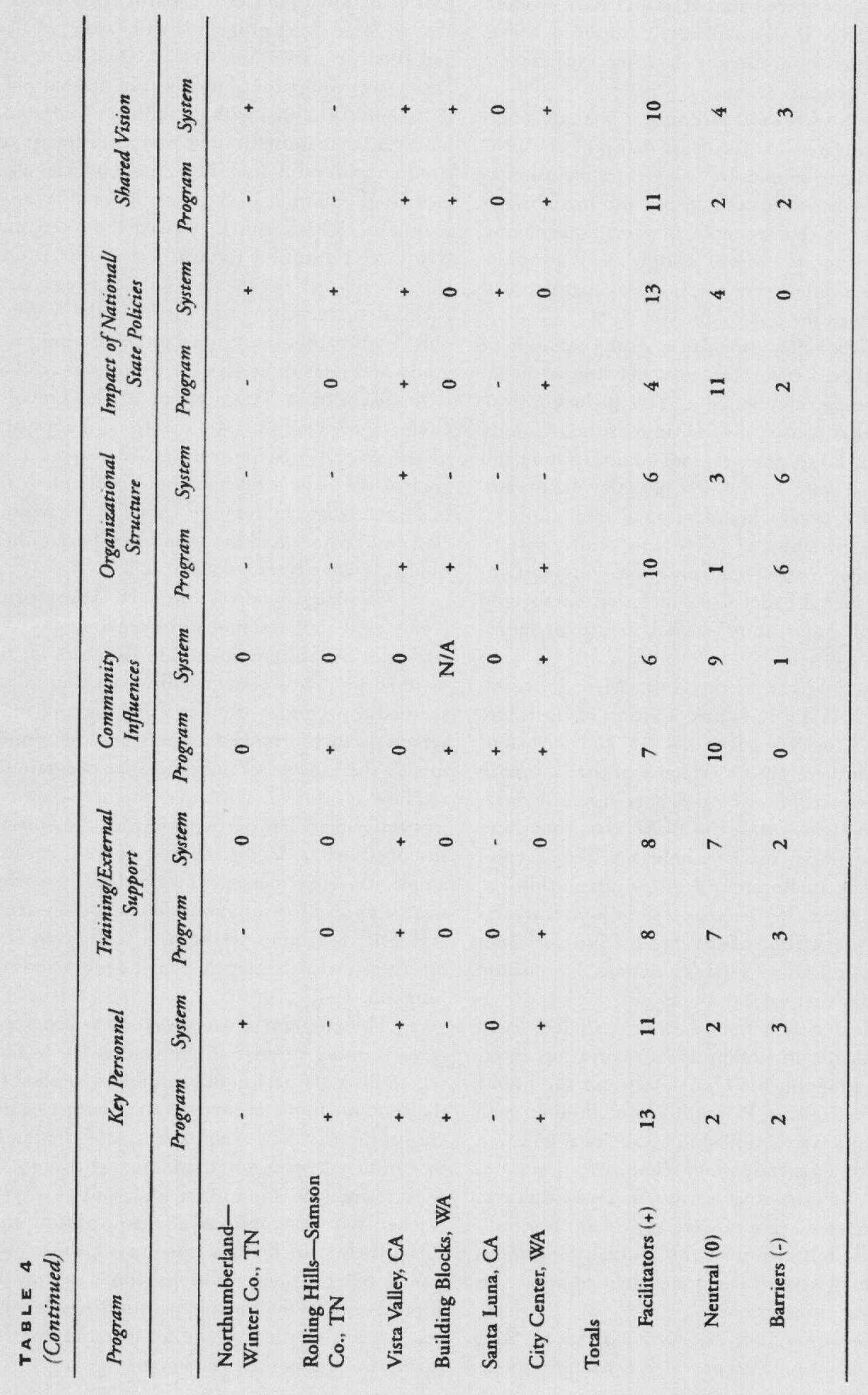


your stuff is somewhere else." The special education teacher agreed that it would have worked much better if she had not "come into somebody's classroom already existing, [to] start a new classroom."

Shared Vision. Holding a shared vision also facilitated inclusion in many of the programs in our sample. In City Center inclusion as a philosophy was woven deeply into the fabric of the program. For example, it was unique among all the programs in our sample, in that adults with disabilities were employed as instructional assistants in the classroom.

Vista Valley provided a strong example of how a shared vision can exist between agencies. Two agencies developed a "Full Inclusion Task Force" that consisted of Head Start and County Office of Education program administrators and interested staff. In the first phase of the organizational process, they developed their philosophy, definitions of inclusion, and steps to implement a successful program. They articulated a shared belief that "inclusion opens up a world of opportunity" with benefits for everyone.

In contrast, at the Costa Mesa program, the teachers did not share a vision of inclusion. The ECE teacher advocated for "full inclusion" although there was no evidence of that approach in her classroom. She did participate in integrated activities with the ECSE class, but Bonnie, the ECSE teacher, held a different view. According to Bonnie, "I guess integration [is] the way we do it-because it's not forever .... It's for a specific time of the day .... But the classroom is still mine. There's a definite big portion of the day that we stay alone."

At a system level, lacking a shared vision was a barrier in Rolling Hills to creating an inclusive program for Head Start and the public school systems. In Hubert County, children with disabilities were enrolled in Head Start; however, there was a general lack of school system responsibility for providing services to those children. Some related services were provided on a pullout basis, but inconsistently. Neither Head Start nor school system personnel defined what was occurring as inclusion.

Impact of State and National Policies. State and national policies provided a strong impetus for some programs to initiate inclusion. The impact of national policies was particularly noticeable in Head Start programs, and those policies had their primary impact at a system level. All Head Start programs abided by the federal policy to enroll children with disabilities. We found, however, that most limited that enrollment to children with mild disabilities. State policies also facilitated inclusion in the Lincoln County program. In 1990 Kentucky passed the sweeping Kentucky Education Reform Act (KERA). On the preschool level, the KERA created a prekindergarten program for "at-risk" 4-yearolds. It also authorized preschool education programs and related services for 3- and 4-year-olds with disabilities. The director of the Lincoln County preschool program described the impact of the educational reform act this way: "The goal of the State ERA preschool program is to make sure that children are served ... in typical classrooms. So we didn't even consider another model. It was never an issue."

Training/External Support. Many programs used staff training or external support as strategies to facilitate inclusion. Teachers in individual programs benefited from visiting other successful programs. At the VIP program, university partners arranged for preschool personnel to visit the Lincoln County inclusive program to see how it worked. For those teachers, "seeing was believing." The partnership with the university operated at the system level as well. For example, university personnel trained teachers who were employed throughout the school system, and VIP classrooms served as a replication site for a university-developed model demonstration program.

The program at Cornwallis also benefited from training offered at the system level. The school district's preschool coordinator applied to the state for funds to increase the number of inclusive preschool classrooms. She used the funds to conduct a week-long summer workshop to train teams consisting of an ECE and an ECSE teacher, two classroom assistants, a parent, and the principal in inclusion using a co-teaching model. She obtained additional funds to provide stipends for follow-up support meetings for the teachers during the year and for materials for the teachers to use in their classrooms. 
Organizational Structure. Organizational structures operated differently at the classroom level and at the district level. At the classroom level the structures that allowed people to communicate, collaborate, and share resources existed among the staff members. For example, in the VIP program, children with disabilities were served in community-based child care programs, and their special education services were provided by itinerant ECSE personnel. The VIP staff set up a communication system with the classroom teachers, related services personnel, and parents through a notebook on each child that was left in the classroom. The ECSE teachers and assistant wrote notes after each visit, as did the related services personnel at some centers. A copy of the notes from the ECSE teacher was sent home to the parents. The ECSE teachers also set up naptime visits with the child care teachers and other staff involved to discuss the child's progress; in some cases, the ECSE teachers also communicated regularly with the VIP staff through telephone conversations. These efforts at the classroom level facilitated the implementation of inclusion in these programs.

At the system level, particularly when two agencies were involved in the provision of inclusion, there were often formal linkages including interagency agreements. For example, Vista Valley Head Start had an interagency agreement with the County Office of Education. According to the Head Start director

\footnotetext{
We started with a simple interagency agreement that was embellished and grew as we learned more about what each program had to offer $\ldots$ and leading up to the point of needing to get beyond our level to get to the level of the Board of Education and the superintendent. Making sure that they were aware of the kinds of programs we were trying to develop ... and the kind of fiscal support that we needed from their level.
}

Barriers were erected in systems where there was no relationship or there was a negative relationship between agencies responsible for the provision of special education services. For example, two Head Start programs (Santa Luna and Building Blocks) had few links to the public school system. In both cases, the school district allowed families to stay in Head Start, but they never referred children to the programs.

Community Influences. Members of the community (particularly parents) facilitated the initiation of inclusion in a number of our programs; we had little evidence that community members were barriers to a program's inception. In some communities, families had participated in inclusive early intervention programs when their children were in Part $C$ programs, and when their children turned 3 years old, they looked for inclusive options. In the Rolling Hills Head Start in Hubert County, one family insisted that their child attend the Head Start program rather than a self-contained class. Based on the family's advocacy, an educational assistant was assigned to the class to work with both Benny and another child with disabilities.

In some programs at the district level, there were strong community influences as well. In the VIP program, community advocacy groups and individual families exerted pressure for the school system to implement an inclusive program. Like the families at one Head Start class, families' previous experiences with inclusive early intervention programs led them to advocate for a continuation of that model. Finally, when the school district formed its Preschool Task Force that focused on the provision of inclusive services, it included family and community members.

\section{DISCUSSION}

Using the literature of educational change, Fullan (1991) generated a conceptual model of factors that researchers have identified as important during initiation and implementation stages of an innovation. Our findings support and extend that model. Specifically, we found there were factors, similar to those described by Fullan, that affected the willingness of programs to adopt and implement inclusion for preschool children. Additionally, we found unique characteristics of preschool education made innovation at that level different from innovation in K-12 schools.

First, in some public school programs change at the preschool level was unrelated to change in the larger system. Administrators de- 
veloped systems for change in preschool programs, but were unwilling to extend the innovation to school-aged students who remained largely in self-contained special education classrooms. Second, in another school district, innovation at the preschool level was viewed as a trial run or jumping off point. Central office administrators used it as an opportunity for principals to get used to the notion that children with and without disabilities should be served together. If that experience was successful, principals would be more likely to accept the change for their school-aged population. Finally, a major way in which change for preschool programs differed from school-aged programs was when multiple agencies were involved, adding to the complexity of the change process. For a number of our programs formal interagency agreements (e.g., between Head Start and a public school system) marked the implementation of inclusion for all preschool children.

The factors that we identified as key influences in the initiation and implementation of inclusion in the preschool programs in our sample were similar to those Fullan (1991) identified in his conceptual model. We found that regardless of where change began, key personnel were a critical factor in initiating and implementing the innovation. According to Fullan, "Initiation of change never occurs without an advocate" ( $p$. 54). In addition, Fullan suggested that the advocacy of central office administrators is particularly important, because they also have the power to block changes that they do not like.

In our programs teachers and principals were also key personnel critical in the change process. As Fullan (1991) notes, however, change initiated by teachers often remains limited to one classroom or one program because teachers do not typically have the power or contacts to widely disseminate their views. In fact, we found that in only one of the five programs where change began with either teachers or principals did the innovation spread beyond that individual program.

Another major facilitator, regardless of the level at which inclusion began, was having a shared vision, or clarity in Fullan's (1991) model. Peck, Richarz et al., (1989) identified this as a key influence as well. They found that when teachers developed and held joint philosophies or when programs integrated approaches to instruction, adoption of an innovation was facilitated.

A final influence that facilitated the initiation and implementation of inclusion was the impact of national and state policies. While those influences operated primarily at the system, rather than the program, level they had an important impact on implementation. Those policies affected Head Start programs, with its mandate that $10 \%$ of children in its programs must have disabilities, as well as special education, with its least restrictive environment (LRE) provision. We found that this factor facilitated inclusion because many programs interpreted policies as mandating inclusion. Fullan (1991), however, points out a dilemma with using policies to guide innovation in that "policies are often ... ambiguous and general" (p. 58). That point was also evident in our sample because the interpretation of the policy varied widely and resulted in programs using a range of inclusive models.

In general, we found few influences that were barriers to adopting inclusion in our programs. One reason for that finding may have been because these programs were in the initiation or implementation phase. Barriers to an innovation may become more evident over time, and may lead eventually to the failure of the program itself.

We did identify organizational structure as a barrier more than any other factor, however. When organizational structure was a barrier, it occurred in programs that had multiple agencies or systems involved in the provision of inclusive services for preschool children.

There are a number of limitations in this study. First, our sample consisted of 18 programs. Although the programs were in four geographical regions nationally, and included public school, Head Start, and community-based programs, they are not representative of all preschool sites. Second, if we consider the history of educational innovation, preschool inclusion is not an innovation. It has existed in a variety of forms since the 1970s. But for any individual program or school district, it becomes an innovation at that time when a decision is 
made to implement it. And although one program in our sample became inclusive in 1978, that was the exception. Thirteen of the 18 programs in our sample began inclusion for preschoolers after 1990.

\section{IMPLICATIONS FOR PRACTICE}

Our findings have a number of implications for practice for those wishing to initiate inclusive programs. First, it is critical to identify key personnel to support the change. Although, it is possible to begin with a single teacher, the likelihood of inclusion spreading beyond a single classroom increases when people in positions of power back the innovation. Second, inclusion, by its very nature, involves teachers, programs, and agencies that approach instruction from different philosophical and educational orientations. Time devoted to ensuring that all participants share, or at least respect, the others' vision is a major influence on successful implementation. Third, inclusion may be more likely to be implemented if training and other resources are provided to practitioners. Training may take the form of seeing other inclusive programs, receiving information about best practices for inclusion, and attending conferences. Buysse, Wesley, and Keyes (1998) also identified joint training as facilitating early childhood inclusion. Finally, implementation of inclusion is strengthened by practitioners who can marshal the support of their community. Families can exert a powerful influence, and, in some cases have been responsible for the existence of inclusion in a program.

The educational community has been grappling with the implementation of systems change efforts to facilitate inclusive practices for several decades. These efforts, however, are still unrealized in many communities. This study demonstrates the complexity of this change process for preschool settings. It also underscores the diversity of program models, as well as the many opportunities for change. Indeed, our findings signal that change can come from a single factor and that "one person can make a difference." While there cannot be, and should not be, one recipe for all programs, these findings suggest potential catalysts for initiating and implementing change in preschool settings.

\section{REFERENCES}

Bronfenbrenner, U. (1979). The ecology of buman development. Cambridge, MA: Harvard University Press. *

Buysse, V., Wesley, P. W., \& Keyes, L. (1998). Implementing early childhood inclusion: Barrier and support factors. Early Childhood Research Quarterly, 13, 169-184.

Cuban, L. (1996). Myths about changing schools and the case of special education. Remedial and Special Education, 17(2), 75-82.

Fullan, M. G. (1991). The new meaning of educational change (2nd ed.). New York: Teachers College Press.*

Glaser, B., \& Strauss, A. L. (1967). The discovery of grounded theory: Strategies for qualitative research. Chicago: Aldine.*

Hargreaves, A. (Ed.). (1997). Rethinking educational change with beart and mind. Alexandria, VA: Association for Supervision and Curriculum Development. ${ }^{*}$

Harvey, J., Voorhees, M. D., \& Landon, T. (1997). The role of the state department of education in promoting integrated placement options for preschoolers: Views from the field. Topics in Early Childhood Special Education, 17, 387-409.

Huberman, A. M., \& Miles, M. B. (1984). Innovation up close. New York: Plenum Press. ${ }^{*}$

Kentucky Education Reform Act of 1990 (KERA). 1990 RS HB 940 AN ACT relating to education. Kentucky State Government.

Lincoln, Y. S., \& Guba, E. G. (1985). Naturalistic inquiry. Newbury Park, CA: Sage.*

McDonnell, A. P., Brownell, K., \& Wolery, M. (1997). Teaching experience and specialist support: A survey of preschool teachers employed in programs accredited by NAEYC. Topics in Early Childhood Special Education, 17, 263-285.

McLaughlin, M. W. (1990). The Rand change agent study revisited: Macro perspectives and micro realities. Educational Researcher, 19(9), 11-16.

Odom, S. L., Horn, E. M., Marquart, J. M., Hanson, M. J., Wolfberg, P., Beckman, P., Lieber, J., Li, S., Schwartz, I., Janko, S., \& Sandall, S. (1999). On the forms of inclusion: Organizational context and individualized service models. Journal of Early Intervention, 22, 185-199. 
Peck, C. A., Furman, G. C., \& Helmstetter, E. (1993). Integrated early childhood programs: Research on implementation of change in organizational contexts. In C. A. Peck, S. L. Odom, \& D. D. Bricker (Eds.), Integrating young children with disabilities into community programs (pp. 187-205). Baltimore: Paul Brookes.*

Peck, C. A., Hayden, L., Wandschneider, M., Peterson, K., \& Richarz, S. A. (1989). Development of integrated preschools: A qualitative inquiry into sources of concern by parents, teachers, and administrators. Journal of Early Intervention, 13, 353-364.

Peck, C. A., Richarz, S. A., Peterson, K., Hayden, L., Meneur, L., \& Wandschneider, M. (1989). An ecological process model for implementing the least restrictive environment mandate in early childhood programs. In R. Gaylord-Ross (Ed.), Integration strategies for students with handicaps (pp. 281-298). Baltimore: Paul Brookes.*

Wolery, M., Holcombe-Ligon, A., Brookfield, J., Huffman, K., Schroeder, C., Martin, C. G., Venn, M. L., Werts, M. G., \& Fleming, L. A. (1993). The extent and nature of preschool mainstreaming: A survey of general early educators. Journal of Special Education, 27, 222-234.

ABOUT THE AUTHORS

joan lieber (CEC \#263), Professor, The University of Maryland, College Park. MARCI J. hanson (CEC\#1174), Professor, San Francisco State University, California. paula J. beckman (CEC \#263), Professor, University of Maryland, College Park. SAMUEL L. ODOM, (CEC \#407), Professor, Indiana University, Bloomington. SUSAN L. SANDALL, (CEC \#949), Assistant Professor; ILENE $S$. schwartz, (CEC \#949), Associate Professor, University of Washington, Seattle. EVA HORN, (CEC \#665), Associate Professor, University of Kansas, Lawrence. RUTH WOLERY (CEC \#617) Associate Professor of the Practice, Vanderbilt University, Nashville, Tennessee.

Correspondence concerning this article should be addressed to Joan Lieber, 1308 Benjamin, Department of Special Education, University of Maryland, College Park, MD 20742. E-mail: j139@umail.umd.edu

This work is supported by Project No. HO24K40004 (Early Childhood Research Insti- tute on Inclusion) from the U.S. Department of Education.

Manuscript received September 1999; manuscript accepted February 2000.

\section{Book}

*To order books referenced in this journal, please call $24 \mathrm{hrs} / 365$ days: 1-800-BOOKSNOW (266-5766) or 1-732-728-1040; or visit them on the Web at http://www.BooksNow.com/Exceptional Children.htm. Use Visa, M/C, AMEX, Discover, or send check or money order + \$4.95 S\&H (\$2.50 each add'l item) to: Clicksmart, 400 Morris Avenue, Long Branch, NJ 07740; 1-732-728-1040 or FAX 1-732-7287080 .

\section{INDEX OF ADVERTISERS}

AFB Press, $p 82$

California State University, Northridge, p 20

Charles Thomas, $p 1$

The Council for Exceptional Children, p 34, 50, 81, 135, 144, cover 2, cover 3 and cover 4

SAIC, p 20

Saxon Publishers, p 82

Utah Schools, p 137 